\title{
Financial capital, constraints, partners, and performance: An empirical analysis of Indonesia SMEs
}

\author{
I Wayan Widnyana ${ }^{1 *}$, I Made Dauh Wijana ${ }^{2}$, Almuntasir $^{3}$ \\ ${ }^{1}$ Department of Management, Faculty of Economy, Universitas Mahasaraswati, Denpasar, \\ Indonesia \\ ${ }^{2}$ Department of Management, Faculty of Economy, Universitas Mahasaraswati, Denpasar, \\ Indonesia \\ ${ }^{3}$ Department of Management, Faculty of Economics and Business, Universitas Gadjah \\ Mada, Yogyakarta, Indonesia \\ *Corresponding Author(s) Email: wywid@unmas.ac.id
}

\section{ABSTRACT}

Indonesia's small and medium enterprises (SMEs) are considered the backbone of the national economy. However, the fact that SMEs still contribute less to the national gross domestic product (GDP) in terms of valueadded, need to be addressed. While previous studies mainly focused on financial (access) constraints as one of the major constraints faced by small enterprises which affect their growth and performances, this study aims to extend the relationship between capital and financial performance of Indonesia SMEs with the moderating effect of financial constraints and partners. This study is different from others as it uses a bigger panel dataset which is about 4.36 million SMEs in Indonesia and is the first to explore the role of financial partners comprehensively. Moreover, the panel regression model with geographic analysis unit uses as a data analysis method. The results of the study show that financial capital has a positive and significant effect on the financial performance of SMEs. Furthermore, while the moderation role of financial partners on the relationship between financial capital and financial performance of Indonesia SMEs was failed to prove, the negative moderation effect of financial constraints was able to prove in this study.

Keywords: Small and Medium Enterprises (SMEs);

Financial Performance; Capital; Financial Constraints; Financial Partners
JEL Code:

C23, E22, G21, G28, L26,

$\mathrm{P} 12$

DOI:

10.31106/jema.v18i2.11318

Article History:

Received 2021-06-26

Reviewed 2021-07-29

Revised 2021-08-14

Accepted 2021-08-29

Licensed:

CC-BY 


\section{Introduction}

Indonesia is one of the countries with the largest number of small-medium enterprises (SMEs) around the world. As of 2018, there are more than 62 million SMEs active (which represent 99.98 percent of all enterprises) in the country (Dinutistomo \& Lubis, 2021). In terms of economic impact, SMEs accounted for almost $60 \%$ of Indonesia's total Gross Domestic Product (GDP) in 2018. SMEs also play a significant role to enhance Indonesia's total employment rate with a contribution of 97.02 percent in 2018. However, despite these major contributions, the survey result from the National Agency of Statistics shows that their average operating profit tended to be corrected by $10.29 \%$ which is resulted in the downward of their average income by $3.88 \%$ annually from 2017 to 2019 . Even worse, the pandemic of COVID-19 in early 2020 caused $48.6 \%$ of the total of 62 million units of SMEs to close their business due to a drastic decline in sales number (Sadjiarto et al., 2020; Tambunan, 2011).

Numerous factors could affect SME's performances, including capital issues, raw materials, marketing, competitors, energy, infrastructure, labor, weather, and others (Prasetya et al., 2021; Zamrudi \& Wicaksono, 2018). Rosengard \& Prasetyantoko (2011) highlighted the perplexing paradox of Indonesia's financial sector related to SMEs which is although over the last decade most of Indonesia's commercial banks are liquid and profitable, and has positive performance of the national economics, SMEs are increasingly experiencing a credit crunch. According to the National Agency of Statistics (2019), there were more than 85\% of Indonesian SMEs are relying on their capital (internal capital) and have no support from external capital, including banks, venture capital, cooperation, and others. Even worse, MSMEs in Indonesia have a financial inclusion rate of roughly 30\%, with 76.1 percent of them receiving finance from banks and $23.9 \%$ of them getting funding from a non-bank financial institution (Bank of Indonesia, 2015). Dinutistomo \& Lubis (2021) argues that these conditions occur because of the low credit market information quality exchanges between creditors and lenders. Thus, SMEs are often being subjected to tighter loan restrictions due to their high credit risk profiles. However, several studies found the opposite as there is a negative relationship between the proportion of SMEs lending and bank risk level and there was a positive influence between SMEs credit and banks profitability (Boadi et al., 2017; Shihadeh et al., 2019).

Furthermore, the relationship between capital and SME performance has been widely discussed globally covering various aspects of capital including intellectual capital, social capital, human capital, intellectual capital, and financial capital. Studies from Beretta et al. 
(2019), Dabić et al. (2019), Paoloni et al. (2021), and Sardo et al. (2018) confirms that intellectual capital has positive associations with SMEs business performances of high-tech, non-high-tech companies, small and medium-sized hotel, agri-food firms, and other sectors. $\mathrm{Xu} \& \mathrm{Li}$ (2019) even added that intellectual capital is positively associated with firm earnings, operation efficiency, and profitability. Along with that finding, social capital and financial capital also have shown that it has positive and significant influences on business (financial) performances among SMEs around the word (Abbas, 2018; Adlešič \& Slavec, 2012; Boohene et al., 2019; Chittithaworn et al., 2011; Fatoki, 2011; Philip, 2011; Omar \& Azmi, 2020; Sombolayuk et al., 2019; Utari \& Dewi, 2014). Nakku et al. (2020) added that the effect of financial capital on SME's performance will be stronger when government support existed. Meanwhile, several studies also confirm that financial constraints are one of the factors that affect the relationship between SMEs capital and performance. They concluded that financial constraints have a negative moderating effect on SMEs performance, the relationship will be stronger when the company has low financial constraints, and vice versa (Altaf \& Ahmad, 2019; Baños-caballero et al., 2014; Kaushik \& Chauhan, 2019; Kowsari \& Shorvarzi, 2017; Laghari \& Chengang, 2019).

This study differs from other studies, for three reasons. First, we will examine the relationship between capital and financial performance of 4.36 million SMEs across all sectors and regions in Indonesia. So far, research on SMEs has focused on certain sectors or regions, so the results may not reflect actual conditions. Therefore, testing on 4.7 million SMEs is expected to reflect more accurate results. Second, we examine the relationship using panel data for three years, to be able to provide more complete information with a high degree of variability and be able to explain the relationship between periods, both short-term and long-term. Third, we will explore the role of financial partners in the relationship between capital and the financial performance of SMEs. The role of financial partners in the relationship between capital and financial performance has never been studied by anyone, and we are the first to explore it. So far, partnership relationships in the context of SMEs are dominantly carried out in supply chain partnerships, as was done by Sukwadi et al. (2013) and Mofokeng \& Chinomona (2019). Therefore, exploring the role of financial partners in this relationship is expected to make a positive contribution to the development of science and research methodologies, especially in the field of entrepreneurship. In addition, an assessment of the role of this financial partner can also identify the efforts of the government and other stakeholders. Thus, the results of this study are also expected to provide practical contributions, which can be used as a consideration for formulating related policies. 


\section{Literature Review}

\section{Small Medium Enterprises (SMEs)}

Small and Medium Enterprises (SMEs) is a term that denotes a business entity, with certain criteria. SMEs are divided into three groups, namely micro, small and medium enterprises. Definitions and terms of SMEs vary from country to country. The European Commission (2015) defines micro-enterprises as enterprises with an annual number of units of work less than 10 with an annual turnover or total annual balance sheet less than or equal to $€ 2$ million. Small businesses have an annual number of work units of less than 50 with an annual turnover or total annual balance sheet less than or equal to $€ 10$ million. Meanwhile, medium-sized enterprises have an annual number of work units of less than 250 with an annual turnover or total annual balance sheet less than or equal to $€ 50$ million. Meanwhile, they define micro-enterprises as businesses that have less than 10 employees with total assets or total annual sales of less than or equal to $\$ 100,000$. Moreover, while small businesses have more than 10 employees less or equal to 50 people, with total assets or total but annual sales of more than $\$ 100,000$ but less or equal to $\$ 3$ million, medium-sized is classified as businesses that have more than 50 employees but less or equal to 300 people, with total assets or total annual sales of more than $\$ 3$ million but less or equal to $\$ 15$ million.

In Indonesia, the definition of SMEs can refer to Law no. 20 of 2008. In the law, microenterprises are defined as businesses that have a maximum wealth of IDR 50 million, with a maximum turnover of IDR 300 million. Small businesses are defined as businesses that have assets of more than IDR 50 million to IDR 500 million, with a turnover of more than IDR 300 million to IDR 2.5 billion. Meanwhile, medium-sized businesses are defined as businesses that have assets of more than IDR 500 million to IDR 10 billion, with a turnover of more than IDR 2.5 billion to IDR 50 billion. Besides being defined by a quantitative approach, SMEs in Indonesia is also defined by a qualitative approach. In this case, the National Agency Statistics uses the number of workers in defining it, where micro-enterprises have a maximum of 4 permanent workers, small businesses 5 to 19 people, and medium-sized businesses 20 to 99 people.

In general, SMEs are business entities that are not legal entities or are often referred to as informal businesses or individual companies. Most are managed directly by the owners, who are assisted by family members. The SME decision-making system is quite flexible, informal, and relies on personal encouragement from its executives (Ayandibu \& Houghton, 2017). Decision-making systems are often automated and not based on accurate business analysis. 
Viewed from the operational aspect, they generally have a narrow reach with a simple organizational structure, rely less on technology, and have low risk (Gronum et al., 2012).

According to the World Bank (2008) reports, SMEs play an important role in the country's economy, because they are the engine of economic growth. They are important for creating competitive and efficient markets, and they are important for alleviating poverty. Therefore, all parties must prioritize it in all respects so that its growth and development are maintained and getting better from time to time. However, the fact is that until now, they are difficult to develop. Olawale \& Garwe (2010) stated that two factors affect their performance so that it often hinders their growth, namely internal and external factors. Internal factors include financial and management constraints, while external factors include economic, market, and infrastructure factors. Meanwhile, Ayandibu \& Houghton (2017) have summarized various problems that are often experienced by SMEs, including lack of access to finance, lack of collateral, inadequate government support, high loan interest rates, insufficient demand, inadequate marketing research, the location is not strategic, high competition, poor credit record, high production costs, lack of information technology, high taxes, lack of entrepreneurial experience and knowledge, and lack of business networks.

\section{Financial Capital and Financial Performance of SMEs}

One theory that is often used to explain the performance of companies, including SMEs is the resource-based view (RBV). This theory focuses on managerial attention to the company's internal resources, both tangible and intangible. Resources should not be embedded in organizational routines or practices, organizational reputation, culture, knowledge, experience, relationships or networks, etc. For SMEs, internal and external capital is used to maintain and increase their competitive advantage (Eniola \& Ektebang, 2014). Lack of financial capital can hinder SMEs (Abiodun \& Amos, 2018; Eniola \& Entebang, 2017).

In general, SME capital consists of two, namely internal capital (own capital) and external capital. Internal capital is capital that comes from the founder or owner and is generally very limited. External capital is other than internal capital. External capital can come from bank loans and financing from other financing, grants, personal loans, etc. External capital, especially from financing, is generally unlimited, but most SME institutions find it difficult to access it. Access the capital needed to acquire resources to take advantage of business opportunities. Lack of physical resources can fail them (Fatoki, 2011). According to Bolingtoft et al. (Fatoki, 2011), to build and maintain SMEs, entrepreneurs need to have 
access to various types of resources, including human resources, physical capital, and financial capital, each of which plays a different role but is equally important to the life cycle. Furthermore, they also stated that there are many reasons related to the failure of SMEs, one of the most important is the unavailability of capital, thus impeding their survival and growth.

The important role of capital on the performance of SMEs has been widely studied in various countries, including Thailand (Chittithaworn et al., 2011), Bangladesh (Philip, 2011), Malaysia (Omar \& Azmi, 2020), and South Africa (Fatoki, 2011). Specifically in Indonesia, research on the relationship between capital and SME performance has also been carried out, for example, Abbas (2018) and Sombolayuk et al. (2019) in Makassar City, Utari \& Dewi (2014) in Denpasar. Capital is positively related to the performance of SMEs, where a capital increase will encourage better SME performance, and vice versa.

$\mathrm{H}_{1}$ : $\quad$ Financial capital is positively related to financial performance.

\section{The Role of Financial Constraints on the Relationship of Capital and Financial Performance of SMEs}

Financial constraints refer to a condition where the company has broad access to profitable investment opportunities but has limited funds to fund these opportunities. Financial constraints are a topic that is highlighted in the context of SMEs because SMEs are the main drivers of economic growth, but the majority always experience financial constraints, thus failing to execute profitable investment opportunities (Belas et al., 2017). Financial constraints for SMEs are generally caused by the limited availability and unclear information so that the prospects for business growth are doubtful. As a result, banks or other funding sources are unwilling to accept their proposals. In addition, business legality and collateral also play an important role in these financial constraints (Lukas Menkhoff et al., 2012; Rahman et al., 2016). In general, SMEs are informal or individual businesses, with a limited number of assets. As a sole proprietorship, the assets of SMEs are inseparable from the personal assets of their owners. This is what makes it difficult for them to access external finance, and if it is accessible, the amount of funds is very limited. Therefore, Olawale \& Garwe (2010) stated that financial constraints are one of the factors that greatly affect the performance of SMEs. The same thing was stated by (Bodlaj et al., 2020), where financial constraints can hinder innovation and creativity, thereby hindering their performance and development.

Financial constraints have a strong moderate effect on the relationship between capital and firm performance. In particular, financial constraints harm the relationship. Several 
studies have confirmed this. For example, Altaf \& Ahmad (2019)(Altaf \& Ahmad, 2019), who tested the moderating effect of financial constraints on 437 non-financial firms in India. They found that there is a positive relationship between working capital and firm performance, where the relationship will be stronger in companies with low financial constraints. However, this relationship will weaken in companies with high financial constraints. In line with these findings, Baños-caballero et al. (2014) also found the same thing in non-financial companies in the UK. Financial constraints provide strong support for the relationship between working capital and firm performance. This implies an optimal level of investment in working capital that balances costs and benefits and maximizes firm value (Altaf \& Ahmad, 2019; Kowsari \& Shorvarzi, 2017; Laghari \& Chengang, 2019; Setianto \& Hayuningdyah, 2020).

$\mathrm{H}_{2}$ : Financial constraints have a negative moderating effect on the relationship between capital and financial performance, where the relationship will be stronger when financial constraints are low, and vice versa.

\section{The Role of Financial Partners on the Relationship of Capital and Financial Performance of SMES}

Partnership, in general, can be interpreted as a form of mutually beneficial cooperation between two or more parties to achieve common goals. In the context of SMEs, a partnership can be defined as cooperation between small businesses and large businesses and/or large businesses by taking into account the principles of mutual need, mutual strengthening, and mutual benefit. Classical literature, such as Astley \& Ven (1983), Mcdowell \& Harris (2009), and Nooteboom (2000) has stated that sustainable inter-organizational partnerships in SMEs are important. This is to improve their performance. In Indonesia, efforts to increase the role of SMEs through partnership patterns are regulated in the Presidential Decree No. 127 of 2001, concerning MSMEs and Partnerships, which states that it is necessary to have a type of business that is reserved for small businesses and open opportunities for medium or large performance with the conditions of the partnership.

The concept of partnership in SMEs is a business strategy used for business development. Partnerships in SMEs can be carried out in all aspects, such as finance, raw materials, marketing, capital goods, etc. Following Law No. 20 of 2008, partnerships in SMEs can be in the form of:

1. The nucleus-plasma partnership pattern, namely, the partnership relationship between small or large businesses as the core company fosters and develops small businesses that 
become plasma by providing technical guidance, technology development, providing production facilities, and providing other assistance needed to increase effectiveness, efficiency, and productivity;

2. Subcontracting partnership pattern, namely a partnership relationship where the partner group produces the components needed by the partner company as part of its production;

3. The pattern of general trade cooperation, namely, a partnership relationship where the partner group provides the needs needed by the partner company and the partner company markets the production of the partner group;

4. The pattern of profit-sharing cooperation, namely, partnership relationships carried out by large and small businesses, the results of which are calculated from the net results of the business and if they experience mutual losses by the agreement;

5. Operational cooperation patterns, namely partnerships carried out by large or mediumsized businesses with micro-enterprises to carry out a joint business using assets and/or business rights that are jointly owned;

6. The pattern of joint ventures, for example, partnerships carried out by micro and small businesses to carry out joint economic activities, in which each party contributes capital and shares the results and risks proportionally;

7. Other cooperation patterns, namely partnerships other than those already mentioned.

In the financial context, partnerships are generally for two things. First, increase capital. Second, improve capital management. Therefore, SMEs with financial partners will find it easier to access more capital and be able to manage their finances effectively and efficiently, thereby encouraging better company performance. Thus, financial partners can act as a moderating variable in the relationship between capital and financial performance. This is because on the one hand financial partners can facilitate access to funds for SMEs so that their capital will increase, while on the other hand, they can improve the quality of SMEs in managing their capital so that it will encourage effectiveness, efficiency, and profits.

$\mathrm{H}_{3}$ : Financial partners have a positive moderating effect on the relationship between capital and financial performance, where the relationship will be stronger when the company has financial partners, and vice versa.

The research framework as depicted in Figure 1, consists of three main variables which are financial performance (dependent variables), financial capital (independent variable), financial constraints, and financial partners (moderating variable). Financial capital is thought to have a positive relationship with financial performance, as explained in the RBV theory, which is supported by empirical findings from several researchers (Abbas, 2018; 
Chittithaworn et al., 2011; Fatoki, 2011; Omar \& Azmi, 2020; Philip, 2011; Sombolayuk et al., 2019; Utari \& Dewi, 2014). Financial constraints are thought to have a negative moderating effect on the relationship between financial capital and financial performance (Altaf \& Ahmad, 2019; Baños-caballero et al., 2014; Kowsari \& Shorvarzi, 2017; Laghari \& Chengang, 2019; Setianto \& Hayuningdyah, 2020). The relationship between financial capital and financial performance will be very strong when the company is not financially constrained. On the other hand, the relationship will be weak when the company is financially constrained.

Figure 1. Research Framework

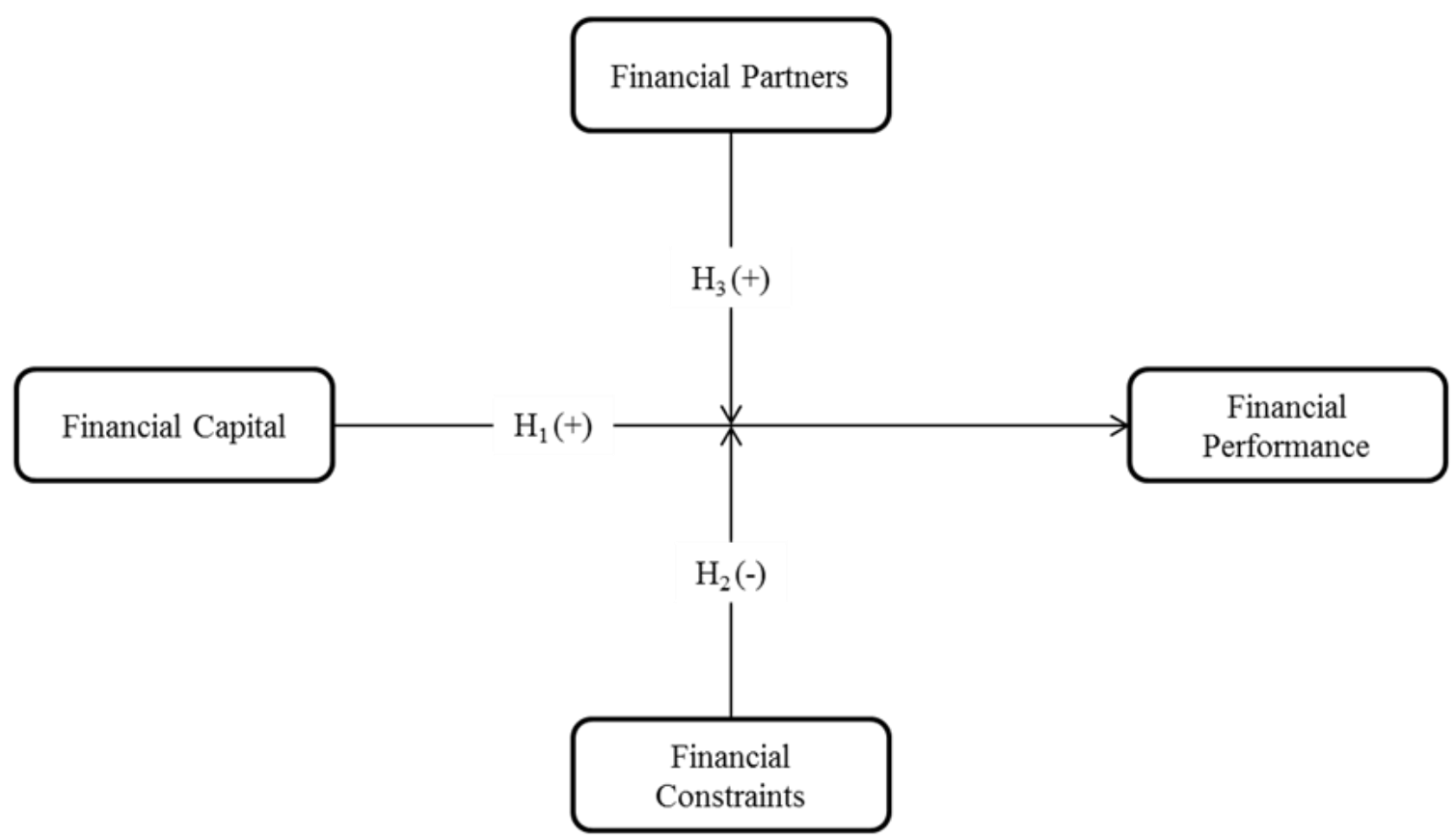

In opposite to financial constraints, financial partners are considered to have a positive moderating effect on the relationship between financial capital and financial performance. The relationship will be very strong when SMEs have financial partners, but the relationship will be weak when SMEs do not have financial partners. When SMEs have financial partners, it is possible to access external capital more easily and the amount of capital obtained is greater than SMEs without financial partners. Meanwhile, other benefits obtained by SMEs with financial partners are quality in managing finances, so that financial management becomes effective, efficient, and profitable. Substantially, these two benefits will drive better financial performance. Financial partners in this study are exploratory because there has been no research examining the relationship between capital and performance. This study is the first to attempt to test this relationship. 


\section{Methods}

The research design uses quantitative methods, precisely existing statistics. According to Lawrence Neuman (2017), existing statistics are research based on statistical data collected by certain parties, such as the government or supervisory agencies, which are carried out by rearranging or providing information in new ways to present more information. He further stated that the existing statistics could be used for descriptive, exploratory, or explanatory purposes. The object of study in the existing statistics is the statistical report itself. In this case, the object of this research is the National Agency of Statistics (2017, 2018, 2019) survey report for 2017, 2018, and 2019 with coverage of more than 4 million Indonesian SMEs annually. Furthermore, the majority of the type of industry in the study is food and beverages (37.13\%), wood industry, goods made of wood, cork, woven goods made of rattan, bamboo, etc. (14.17\%), and apparel (13.25\%). While the minority is the computer, electronic, and optical goods industry $(0.02 \%)$, the electrical equipment industry $(0.03 \%)$, and the motor vehicle, trailer, and semi-trailer industry $(0.06 \%)$. By region, the majority of them are localized in Java (59.63\%), Sumatra (16.07\%), Bali and Nusa Tenggara (9.26\%), Sulawesi $(8.66 \%)$, and Kalimantan $(4.41 \%)$.

The data of this research can be explained in three perspectives. The first perspective, according to its type, this research uses quantitative data, namely data that is expressed in numbers and can be measured. The second perspective, based on the source of data acquisition, this study uses secondary data, namely, data obtained from the National Agency of Statistics (2017, 2018, 2019) survey reports in 2017, 2018, and 2019. The third perspective, based on the period, this study uses panel data. Data analysis used panel regression model - common effect, with ordinary least squares method and the geographical as the unit data analysis. Data analysis was assisted by STATA software. Table 1 below presents the research variables along with their operational definitions and measurements. 
Table 1. Variables, Operational Definitions, and Measurements

\begin{tabular}{|c|c|c|}
\hline Variables & Definition & Measurements \\
\hline $\begin{array}{l}\text { Financial } \\
\text { Performance } \\
\text { (Fin_Perf) }\end{array}$ & $\begin{array}{l}\text { The ability of SMEs to earn } \\
\text { operating profit in the current } \\
\text { year. }\end{array}$ & OPM $=\frac{\text { Operating Income }}{\text { Total Sales }} \times 100 \%$ \\
\hline $\begin{array}{l}\text { Financial Capital } \\
\text { (Fin_Cap) }\end{array}$ & $\begin{array}{l}\text { Total SME capital, which consists } \\
\text { of internal and external capital in } \\
\text { the current year. }\end{array}$ & $\begin{array}{l}\text { Natural logarithm of total } \\
\text { capital. }\end{array}$ \\
\hline $\begin{array}{l}\text { Financial Constraints } \\
\text { (Fin_Const) }\end{array}$ & $\begin{array}{l}\text { A condition where an SME has } \\
\text { broad access to profitable } \\
\text { investment opportunities but does } \\
\text { not have the funds to execute } \\
\text { those opportunities. }\end{array}$ & $\begin{array}{l}\text { A dummy variable, where a } \\
\text { score of } 0 \text { is given to SMEs that } \\
\text { are experiencing financial } \\
\text { constraints, and a score of } 1 \text { is } \\
\text { given to SMEs that are not } \\
\text { experiencing financial } \\
\text { constraints. }\end{array}$ \\
\hline $\begin{array}{l}\text { Financial Partners } \\
\text { (Fin_Part) }\end{array}$ & $\begin{array}{l}\text { A condition, where an SME has a } \\
\text { partnership relationship in the } \\
\text { financial sector. }\end{array}$ & $\begin{array}{l}\text { A dummy variable, where a } \\
\text { score of } 0 \text { is given to SMEs that } \\
\text { are having partners, and a score } \\
\text { of } 1 \text { is given to SMEs that are } \\
\text { not having partners. }\end{array}$ \\
\hline Size (SIZE) & The size of SME. & Total sales. \\
\hline Human Capital (HC) & $\begin{array}{l}\text { Human resources or non-financial } \\
\text { resources are controlled by an } \\
\text { SME to achieve its goals. }\end{array}$ & $\begin{array}{l}\text { The additional amount of the } \\
\text { interaction number of employees } \\
\text { with education level and } \\
\text { entrepreneur education level. }\end{array}$ \\
\hline Social Capital (SC) & $\begin{array}{l}\text { Social resources or non-financial } \\
\text { resources are controlled by an } \\
\text { SME to achieve its goals. In this } \\
\text { case, the source is in the form of } \\
\text { cooperation with other parties } \\
\text { other than cooperation in the } \\
\text { financial sector. }\end{array}$ & $\begin{array}{l}\text { Number of non-financial } \\
\text { cooperation. }\end{array}$ \\
\hline $\begin{array}{l}\text { Regional Economic } \\
\text { Growth (REG) }\end{array}$ & $\begin{array}{l}\text { Regional economic growth, which } \\
\text { reflects the economic conditions } \\
\text { and business climate in the area. }\end{array}$ & $R E G=\frac{G R D P_{t}-G R D P_{t-1}}{G R D P_{t-1}} \times 100 \%$ \\
\hline
\end{tabular}


The econometric models developed for the study can be described as below:

Fin_Perf ${ }_{i t}=\alpha+\beta_{1}$ Fin_Cap $_{i t}+\beta_{2}$ SIZE $_{i t}+\beta_{3} \mathrm{HC}_{i t}+\beta_{4} \mathrm{SC}_{\mathrm{it}}+\beta_{5} \mathrm{REG}_{\mathrm{it}}+\varepsilon_{\mathrm{it}}$

Fin_Perf ${ }_{i t}=\alpha+\beta_{1}$ Fin_Capit $_{i t}+\beta_{2}$ Fin_COnst $_{i t}+\beta_{3}$ Fin_Cap* Fin_Const $_{i t}+\beta_{4}$ SIZE $_{i t}+\beta_{5} \mathrm{HC}_{\mathrm{it}}$

$$
+\beta_{6} \mathrm{SC}_{\mathrm{it}}+\beta_{7} \mathrm{REG}_{\mathrm{it}}+\varepsilon_{\mathrm{it}}
$$

Fin_Perf ${ }_{i t}=\alpha+\beta_{1}$ Fin_Cap $_{i t}+\beta_{2}$ Fin_Part $_{i t}+\beta_{3}$ Fin_Cap* Fin_Part $_{i t}+\beta_{4}$ SIZE $_{i t}+\beta_{5} \mathrm{HC}_{\text {it }}$

$$
+\beta_{6} \mathrm{SC}_{\mathrm{it}}+\beta_{7} \mathrm{REG}_{\mathrm{it}}+\varepsilon_{\mathrm{it}}
$$

Fin_Perf $_{i t}=\alpha+\beta_{1}$ Fin_Cap $_{i t}+\beta_{2}$ Fin_Const $_{i t}+\beta_{3}$ Fin_Part $_{i t}+\beta_{4}$ Fin_Cap* Fin_Const $_{i t}$

$$
+\beta_{5} \text { Fin_Cap* Fin_Part }{ }_{i t}+\beta_{6} \mathrm{SIZE}_{\mathrm{it}}+\beta_{7} \mathrm{HC}_{\mathrm{it}}+\beta_{8} \mathrm{SC}_{\mathrm{it}}+\beta_{9} \mathrm{REG}_{\mathrm{it}}+\varepsilon_{\mathrm{it}}
$$

\begin{tabular}{|c|c|}
\hline Fin_Perf ${ }_{i t}$ & : Financial Performance of SMEs $i$ in the year of \\
\hline Fin_Capit & : Financial capital of SMEs $i$ in the year of $t$ \\
\hline Fin_Const ${ }_{i t}$ & : Financial constraints of SMEs $i$ in the year of $t$ \\
\hline Fin_Partit & : Financial partners of SMEs $i$ in the year of $t$; \\
\hline Fin_Cap* Fin_Const ${ }_{i t}$ & $\begin{array}{l}\text { : The interaction of financial capital and constra } \\
\text { the year of } t ;\end{array}$ \\
\hline Fin_Cap* Fin_Part ${ }_{i t}$ & $\begin{array}{l}: \text { The interaction of financial capital and part } \\
\text { the year of } t ;\end{array}$ \\
\hline SIZE $_{\text {it }}$ & : The Size of SMEs $i$ in the year of $t$ \\
\hline $\mathrm{HC}_{\mathrm{it}}$ & : Human Capital of SMEs $i$ in the year of $t$ \\
\hline $\mathrm{SC}_{\text {it }}$ & : Social Ccapital of SMEs $i$ in the year of $t$ \\
\hline $\mathrm{REG}_{\mathrm{it}}$ & : Economic Growth of Region $i$ in the year of $t$ \\
\hline$\alpha$ & : Constant; \\
\hline$\beta$ & : Coefficient; \\
\hline . & Residual Error. \\
\hline
\end{tabular}

Where:

\section{Result and Discussion}

Table 2 displays the descriptive statistics of the National Agency of Statistics (2017, 2018, 2019) survey reports. From the table, it can be seen that the number of SMEs during the year of observation tends to fluctuate. At the beginning (2017), the number of SMEs reached 4.46 million, thus, in 2018 the number decreased by around $4.49 \%$ to 4.26 million, and lastly in 2019 increased again by about $2.27 \%$ to 4.38 million. To summarize, the average number of SMEs surveyed for the last three years has amounted to 4.37 million. 
Table 2. Descriptive Statistics

\begin{tabular}{|c|c|c|c|c|c|}
\hline & 2017 & 2018 & 2019 & Total & Average \\
\hline No. of SMEs & $4,464,688$ & $4,264,047$ & $4,380,176$ & $13,108,911$ & $4,369,637$ \\
\hline \multicolumn{6}{|l|}{ Fin_Perf } \\
\hline OI (IDR Mill.) & 274,695 & 258,187 & 220,574 & 753,456 & 251,152 \\
\hline OPM (\%) & 46 & 45 & 44 & 134 & 47 \\
\hline Fin_Cap (IDR Mill.) & 327,767 & 262,457 & 280,873 & 871,097 & 290,366 \\
\hline Internal Capital & 268,383 & 222,529 & 245,147 & 736,059 & 245,353 \\
\hline External Capital & 59,384 & 39,878 & 35,725 & 134,987 & 44,996 \\
\hline Bank & 25,284 & 18,362 & 17,807 & 61,453 & 20,484 \\
\hline Venture Capital & 232 & 1,241 & 2,123 & 3,596 & 1,199 \\
\hline Cooperation & 3,442 & 2,546 & 2,434 & 8,422 & 2,807 \\
\hline Pawnshop & 1,196 & 312 & 278 & 1,787 & 596 \\
\hline Government & 1,503 & 2,031 & 701 & 4,235 & 1,412 \\
\hline Others & 27,726 & 15,385 & 12,381 & 55,494 & 18,498 \\
\hline Fin_Const & $1,126,480$ & 752,976 & 983,958 & $2,863,414$ & 954,471 \\
\hline Fin_Part & 31,843 & 34,452 & 26,594 & 92,889 & 30,963 \\
\hline SIZE (IDR Mill.) & 602,462 & 520,644 & 501,447 & $1,624,554$ & 541,518 \\
\hline $\mathrm{HC}$ & $50,397,314$ & $52,768,716$ & $51,369,690$ & $154,535,720$ & $51,511,906$ \\
\hline No. of Employees & $9,394,193$ & $9,836,228$ & $9,575,446$ & $28,805,867$ & $9,601,956$ \\
\hline No School & $1,562,486$ & $1,636,007$ & $1,592,633$ & $4,791,126$ & $1,597,042$ \\
\hline Elementary Sch. & $3,433,645$ & $3,595,212$ & $3,499,894$ & $10,528,751$ & $3,509,584$ \\
\hline Junior High Sch. & $2,626,257$ & $2,368,705$ & $2,305,905$ & $7,300,867$ & $2,433,622$ \\
\hline Senior High Sch. & $5,695,901$ & $5,963,917$ & $5,805,799$ & $17,465,617$ & $5,821,872$ \\
\hline Diploma & 61,456 & 64,348 & 62,642 & 188,446 & 62,815 \\
\hline Higher Education & 169,565 & 177,544 & 172,837 & 519,946 & 173,315 \\
\hline \multicolumn{6}{|l|}{ No. of } \\
\hline Entrepreneurs & $4,464,688$ & $4,264,047$ & $4,380,176$ & $13,108,911$ & $4,369,637$ \\
\hline No School & 806,811 & 844,775 & 822,378 & $2,473,964$ & 824,655 \\
\hline Elementary Sch. & $1,524,154$ & $1,595,871$ & $1,553,561$ & $4,673,586$ & $1,557,862$ \\
\hline Junior High Sch. & 914,606 & 957,642 & 932,253 & $2,804,501$ & 934,834 \\
\hline Senior High Sch. & 899,807 & 942,147 & 917,168 & $2,759,122$ & 919,707 \\
\hline Diploma & 36,987 & 38,728 & 37,701 & 113,416 & 37,805 \\
\hline Higher Education & 114,898 & 120,305 & 117,115 & 352,318 & 117,439 \\
\hline $\mathrm{SC}$ & 391,347 & 409,761 & 398,898 & $1,200,006$ & 400,002 \\
\hline Avg. REG (\%) & 9.58 & 9.19 & 6.70 & 25.47 & 8.49 \\
\hline
\end{tabular}


The financial performance of SMEs also tends to decline during the observation year. In 2017 their total operating income was IDR 274.70 billion, then in 2018 it decreased by $6.01 \%$ to IDR 258.19 billion, and in 2019 it fell again by $14.57 \%$ to IDR 220.57 billion. Their average total operating income during the year of observation was IDR 251,152.25 billion or around IDR 57.48 million per SME. This amount when referring to the criteria in Law no. 2 of 2008 is included in the micro-business group. So, the average number of SMEs in Indonesia are micro-enterprises, not small and not medium enterprises. The decline in operating income resulted in their operating profit margin (OPM) also tends to fall. In 2017 their OPM was $45.60 \%$, then in 2018 it fell to $44.59 \%$, and in 2019 it fell again to $43.99 \%$. However, their OPM average is still positive, which is $44.73 \%$ per year. Their financial capital also seems to decline from year to year, both internal and external capital. In 2017 their total financial capital was IDR 327,767.24 billion, which consisted of internal capital of 81.88\% (IDR 268,382.99 billion) and external capital of 18.12\% (IDR 59,384.09 billion). Financial capital decreased in 2018 by $19.93 \%$ to IDR 262,456.94 billion, consisting of $84.79 \%$ internal capital and $15.19 \%$ external capital. In 2019, their total financial capital again increased by about $7.02 \%$ to IDR $280,873.39$ billion, consisting of $87.28 \%$ internal capital and $12.72 \%$ external capital. During the year of observation, their average total capital was IDR 290,365.86 billion, most of which (84.50\%) was internal capital and only $15.50 \%$ external capital. If averaged per SME, the total financial capital is around IDR 66.45 million per SME. SME capital is divided into two types, namely internal capital and external capital. Throughout the observation year (2017-2019), both tend to move downward from year to year. However, the decline in external capital was greater than the decline in internal capital. Specifically for external capital, about $7.05 \%$ came from banking, venture capital $(0.41 \%)$, cooperatives $(0.97 \%)$, pawnshops $(0.21 \%)$, government $(0.49 \%)$, and other sources $(7.37 \%)$. The data clearly explains that the development of SMEs in Indonesia is almost entirely dependent on capital from their owners, while external capital does not contribute to its development, be it capital from banks, venture capital, or others.

In contrast to its capital and financial performance, the number of SMEs that are financially constrained tends to decline from year to year. The number of SMEs that were financially constrained in 2017 was IDR 1.13 million or around 25.23\%. Furthermore, in 2018 the number of SMEs with financial constraints decreased by around $33.16 \%$ to IDR 752.98 thousand, but in 2019 increased again beyond $30.68 \%$ to IDR 983.96 thousand. During the year of observation, the average number of SMEs with financial constraints reached IDR 954.47 thousand, or about $21.84 \%$ of the existing SMEs. Meanwhile, the 
average number of SMEs that have financial partnership relationships is only 30.96 thousand or $0.71 \%$ of the average existing SMEs. This number tends to decrease from year to year. In 2017 the number of SMEs with financial partners was 31.84 thousand, then in 2018 it increased to 34.45 thousand, and in 2019 it fell drastically to 26.59 thousand or decreased by around $22.81 \%$. Besides, the size of SMEs as measured by total sales is an average of IDR 541,518.10 billion or around IDR 123.93 million per SME per year. If referring to Law no. 20 of 2008, then they are also classified as micro-enterprises, not small businesses, and not medium-sized businesses. Their size decreases from year to year. In 2017 their total sales reached IDR $602,462.44$ billion, then in 2018 it fell by around 13.58\% to IDR 520,644.44 billion, and in 2019 it fell again by around 3.69\% to IDR 501,447.43 billion. It also shows that their performance is poor as previously described.

In contrast to financial capital, the human capital of SMEs tends to increase. This can be seen from the number of employees, with the education level of employees with a better level of education, as well as the level of entrepreneurial education. The average number of employees working in the SME sector reaches 9.60 million people per year. Or about 2 people per SME. (60.63\%) have a high school education, $36.55 \%$ have an elementary school education, $25.35 \%$ have a junior high school education, $16.63 \%$ don't go to school, $1.81 \%$ have higher education, and $0.65 \%$ have diploma education. Employees with basic education tend to decline from year to year, while employees with education are increasing. Meanwhile, in terms of entrepreneurship, the largest (35.65\%), including elementary, junior high (21.39\%), high school (21.05\%), not in school (18.87\%), higher education $(2.69 \%)$, and diploma $(0.87 \%)$. The social capital of SMEs as measured by the number of drawn nonfinancial partnerships tends to increase. In 2017 the number of non-financial partnership relationships owned by SMEs was 391.35 thousand, thus, in 2018 it increased by $4.71 \%$ to 409.76 thousand, but in 2019 it decreased by about $2.65 \%$ to 398.90 thousand. The average number of non-financial partnership relationships during the year of observation was 400,000 thousand relationships or about $8.49 \%$ of the total existing SMEs. This shows that the social capital of SMEs in Indonesia is very low. Finally, during the year of observation, the economic condition and business climate were not good. This is reflected in the regional economic growth (Reg) which has decreased from year to year. In 2017 regional economic growth was $9.58 \%$, but in 2018 it fell to $9.19 \%$, and in 2019 it fell again to $6.70 \%$. The average regional economic growth during the year of observation was $8.49 \%$. This condition can trigger an increase in SME input-output prices and a decrease in consumer purchasing power which can harm the performance of SMEs. 
Relationship between Financial Capital and Performance: Short-Term vs. Long-term

Table 3. Panel Regression

\begin{tabular}{|c|c|c|c|c|c|c|c|c|}
\hline & \multicolumn{6}{|c|}{ Short-Term } & \multirow{2}{*}{\multicolumn{2}{|c|}{$\begin{array}{c}\text { Long-Term } \\
2017-2019 \\
\end{array}$}} \\
\hline & \multicolumn{2}{|c|}{2017} & \multicolumn{2}{|c|}{2018} & \multicolumn{2}{|c|}{2019} & & \\
\hline & $\boldsymbol{\beta}$ & $\mathbf{t}$ & $\beta$ & $\mathbf{t}$ & $\boldsymbol{\beta}$ & $\mathbf{t}$ & $\boldsymbol{\beta}$ & $\mathbf{t}$ \\
\hline \multicolumn{9}{|c|}{ Panel A (General) } \\
\hline Fin_Cap & 0.949 & $42.897 * * *$ & 0.802 & $22.434 * * *$ & 0.948 & $14.633 * * *$ & 0.889 & $37.348 * * *$ \\
\hline SIZE & 0.941 & $89.009 * * *$ & 0.979 & $43.434 * * *$ & 0.989 & $27.316^{* * *}$ & 0.987 & $71.950 * * *$ \\
\hline $\mathrm{HC}$ & 0.082 & $2.043 * *$ & 0.059 & 0.743 & 0.089 & 0.544 & 0.078 & 1.198 \\
\hline $\mathrm{SC}$ & 0.001 & 0.423 & -0.003 & -0.416 & 0.005 & 0.404 & 0.005 & 0.045 \\
\hline REG & 0.081 & $2.119^{* *}$ & -0.054 & -0.718 & -0.051 & -0.325 & -0.066 & -1.064 \\
\hline $\mathrm{R}^{2}$ & \multicolumn{2}{|c|}{0.998} & \multicolumn{2}{|c|}{0.976} & \multicolumn{2}{|c|}{0.999} & \multicolumn{2}{|c|}{0.999} \\
\hline F-Stat. & \multicolumn{2}{|c|}{$906.302 * * *$} & \multicolumn{2}{|c|}{$292.561 * * *$} & \multicolumn{2}{|c|}{$397.866 * * *$} & \multicolumn{2}{|c|}{$244.263 * * *$} \\
\hline \multicolumn{9}{|c|}{ Panel B (by Types of Capital) } \\
\hline Int_Cap & 0.842 & $29.758 * * *$ & 0.741 & $21.219 * * *$ & 0.857 & $11.289 * * *$ & 0.798 & $32.533 * * *$ \\
\hline Ext_Cap & 0.131 & $13.828 * * *$ & 0.073 & $5.489 * * *$ & 0.095 & $4 . .160 * * *$ & 0.099 & $10.851 * * *$ \\
\hline SIZE & 0.960 & $66.923 * * *$ & 0.980 & $41.529 * * *$ & 0.989 & $25.226 * * *$ & 0.987 & $69.413 * * *$ \\
\hline $\mathrm{HC}$ & 0.074 & 1.429 & 0.107 & 1.210 & 0.080 & 0.460 & 0.072 & 1.056 \\
\hline $\mathrm{SC}$ & 0.004 & -0.006 & -0.005 & -0.694 & 0.007 & 0.522 & 0.005 & -0.055 \\
\hline REG & -0.068 & -1.372 & -0.098 & -1.171 & -0.046 & -0.275 & -0.060 & -0.925 \\
\hline $\mathrm{R}^{2}$ & \multicolumn{2}{|c|}{0.978} & \multicolumn{2}{|c|}{0.977} & \multicolumn{2}{|c|}{0.999} & \multicolumn{2}{|c|}{0.999} \\
\hline F-Stat. & \multicolumn{2}{|c|}{$248.281^{* * * *}$} & \multicolumn{2}{|c|}{$233.985^{* * *}$} & \multicolumn{2}{|c|}{$304.209 * * *$} & \multicolumn{2}{|c|}{$191.513^{* * *}$} \\
\hline \multicolumn{9}{|c|}{ Panel C (by Sources of Capital) } \\
\hline Individual & 0.895 & $13.371 * * *$ & $0.688 * * *$ & $8.497 * * *$ & 1.089 & $7.109 * * *$ & 0.841 & $21.679 * * *$ \\
\hline Vent. Cap & 0.001 & -0.268 & $-0.005 * * *$ & -0.565 & 0.002 & 0.083 & 0.001 & 0.123 \\
\hline Bank & 0.047 & $3.671 * * *$ & $0.055^{* * *}$ & $2.430 * * *$ & 0.004 & 0.065 & 0.057 & $4.799 * * *$ \\
\hline Coop. & -0.005 & -0.529 & $0.025 * * *$ & 2.182 & -0.037 & -1.569 & 0.012 & 1.917 \\
\hline Panwshop & -0.007 & -1.548 & $0.011 * * *$ & 1.702 & -0.003 & -0.272 & -0.001 & -0.363 \\
\hline Govmnt. & 0.001 & 0.052 & $-0.002 * * *$ & -0.318 & -0.013 & -1.024 & -0.007 & -1.066 \\
\hline Others & -0.017 & -0.925 & $0.003 * * *$ & 0.640 & 0.012 & 0.634 & -0.002 & -0.691 \\
\hline SIZE & 0.998 & $26.759 * * *$ & $0.972 * * *$ & $19.173 * * *$ & 0.917 & $17.554 * * *$ & 0.989 & $44.300 * * *$ \\
\hline $\mathrm{HC}$ & 0.062 & 0.603 & $0.077 * * *$ & 0.487 & 0.588 & 1.759 & 0.222 & $2.150 * *$ \\
\hline $\mathrm{SC}$ & -0.004 & -0.429 & $0.006^{* * *}$ & 0.374 & -0.026 & -0.797 & -0.009 & $-1.067 * * *$ \\
\hline REG & -0.064 & -0.678 & $-0.074 * * *$ & -0.488 & -0.458 & -1.671 & -0.190 & $-1.954^{*}$ \\
\hline $\mathrm{R}^{2}$ & \multicolumn{2}{|c|}{0.991} & \multicolumn{2}{|c|}{0.989} & \multicolumn{2}{|c|}{0.999} & \multicolumn{2}{|c|}{0.999} \\
\hline F-Stat. & 190 & $3 * * *$ & 87.0 & $9 * * *$ & 641 & $17 * * *$ & 493 & $62 * * *$ \\
\hline
\end{tabular}

Notes: *) Significant at $10 \%, * *)$ Significant at 5\%, ***) Significant at $1 \%$ 
The results show that in general (see Table 3, Panel A), financial capital is positively and significantly related to the financial performance of SMEs, both in the short and long term. This means that an increase/decrease in financial capital will trigger an increase/decrease in the financial performance of SMEs, thus supporting our first hypothesis. This finding is in accordance with the RBV theory which explains that internal resources such as financial capital are very important to increase competitive advantage. In the context of SMEs, financial capital plays an important role in financing working capital and long-term assets. The availability of large capital allows them to increase the business productivity effectively and efficiently. An increase in productivity will trigger an increase in sales or revenue and reduce operating costs, thereby driving higher operating profits. In addition, the availability of large financial capital also enables them to execute profitable business opportunities in the future, either through product differentiation or business diversification. On the other hand, limited financial capital will have a negative impact on working capital financing and longterm asset investment. This will affect or even hinder productivity and run profitable business opportunities in the future. This finding also supports findings from (Abbas, 2018; Chittithaworn et al., 2011; Fatoki, 2011; Omar \& Azmi, 2020; Sombolayuk et al., 2019; Utari $\&$ Dewi, 2014). They also find that financial capital is positively related to the performance of SMEs.

The financial capital of SMEs is divided into two types, namely internal capital and external capital. Based on Table 3, Panel B, shows that both types of capital are positively and significantly related to financial performance, both in the short and long term. When compared between the two, the contribution of internal capital to the performance of SMEs is greater than the contribution of external capital. This is due to the high use of internal capital from the SMEs studied. During this observation year (2017-2019), around 84.50\% of the total SME capital was internal capital and only $15.50 \%$ was external capital. Therefore, internal capital has a more dominant role than external capital.

Based on the source of capital (see Table 3, Panel C), individual capital (internal capital) is positively and significantly related to the financial performance of SMEs, both in the short and long term. Meanwhile, capital originating from banks (credit) varies in the short term. In 2017, bank capital was positively related to the financial performance of SMEs, as well as in 2018. However, in 2019, bank capital did not have a significant relationship with the financial performance of SMEs. However, in the long term, capital from banks is positively and significantly related to the financial performance of SMEs. 
The capital that comes from cooperation, in the short term, varies. In 2017 and 2019, this capital did not show a significant relationship with financial performance. In 2018 this capital is positively related to financial performance, but its contribution to performance is very low. In the long term, this capital is positively related to the financial performance of SMEs, but with a very low contribution, especially when compared to contributions from banks. Meanwhile, capital from venture capital, pawnshops, government, and other sources has not shown a significant relationship with the financial performance of SMEs, both in the long and long term.

\section{Moderation Effect}

Table 4. Moderation Effect

\begin{tabular}{|c|c|c|c|c|c|c|c|c|}
\hline & \multicolumn{2}{|c|}{ Model 1} & \multicolumn{2}{|c|}{ Model 2} & \multicolumn{2}{|c|}{ Model 3} & \multicolumn{2}{|c|}{ Model 4} \\
\hline & $\boldsymbol{\beta}$ & $\mathbf{t}$ & $\boldsymbol{\beta}$ & $\mathbf{t}$ & $\boldsymbol{\beta}$ & $\mathbf{t}$ & $\boldsymbol{\beta}$ & $\mathbf{t}$ \\
\hline Fin_Cap & 0.889 & $37.348 * * *$ & 0.855 & $28.017 * * *$ & 0.884 & $34.976 * * *$ & 0.816 & $22.356^{* * *}$ \\
\hline Fin_Const & -------- & -------- & 0.067 & 1.771 & -------- & -------- & 0.225 & $2.522 * *$ \\
\hline $\begin{array}{l}\text { Fin_Cap * } \\
\text { Fin_Const }\end{array}$ & & & -0.003 & -1.805 & --------- & --------- & -0.011 & $-2.544 * *$ \\
\hline Fin_Part & -------- & -------- & -------- & -------- & 0.023 & $0.842 * * *$ & -0.008 & -0.213 \\
\hline Fin_Cap * & & & & & 0001 & 751*火火 & 0007 & 1010 \\
\hline Fin_Part & & & & & -0.001 & -0.121 & 0.001 & $1.0+0$ \\
\hline SIZE & 0.987 & $71.950 * * *$ & 0.987 & $71.695 * * *$ & 0.987 & $71.683 * * *$ & 0.987 & $72.372 * * *$ \\
\hline $\mathrm{HC}$ & 0.078 & 1.198 & 0.072 & 1.005 & 0.066 & $0.999 * * *$ & 0.091 & 1.270 \\
\hline $\mathrm{SC}$ & 0.005 & 0.045 & 0.005 & 0.005 & 0.005 & $0.054 * * *$ & -0.003 & -0.500 \\
\hline REG & -0.066 & -1.064 & -0.059 & -0.886 & -0.056 & $-0.890 * * *$ & -0.076 & -1.151 \\
\hline $\mathrm{R}$ & \multicolumn{2}{|c|}{0.999} & \multicolumn{2}{|c|}{0.999} & \multicolumn{2}{|c|}{0.999} & \multicolumn{2}{|c|}{0.999} \\
\hline $\mathrm{R}^{2}$ & \multicolumn{2}{|c|}{0.999} & \multicolumn{2}{|c|}{0.999} & \multicolumn{2}{|c|}{0.999} & \multicolumn{2}{|c|}{0.999} \\
\hline F-Stat. & \multicolumn{2}{|c|}{$244.263 * * *$} & \multicolumn{2}{|c|}{$176.771 * * *$} & \multicolumn{2}{|c|}{$173.173 * * *$} & \multicolumn{2}{|c|}{$141.122 * * *$} \\
\hline
\end{tabular}

Notes: *) Significant at $10 \%, * *)$ Significant at 5\%,***) Significant at $1 \%$

Table 4, Model 1, shows the results of testing the relationship between financial capital and the financial performance of SMEs. The values in Table 4, Model 1, are the same as those in Table 3, Long-Term column, Panel A. We return to Table 4 for comparison with Model 2, Model 3, and Model 4. As previously explained, financial capital is related positive and significant with the financial performance of SMEs. This finding is in accordance with the explanation of the RBV theory and the findings of other researchers, thus supporting our first hypothesis. 
Model 2 presents the results of testing the moderating effect of financial constraints on the relationship between financial capital and the financial performance of SMEs. The results show that financial constraints are proven to weaken the relationship between financial capital and the financial performance of SMEs, thus supporting our second hypothesis. SMEs experiencing financial constraints will find it difficult to increase their financial capital, especially external capital, such as bank credit or other external sources. Lenders will find it difficult to approve loans from financially constrained SMEs because they are worried about the risk of default. Therefore, lenders may require higher return requirements for financially constrained companies. For SMEs, if they agree to high return terms, it will increase the cost of capital, which will increase their financial costs. So, instead of improving financial performance, they will experience inefficiency. On the other hand, SMEs that experience low financial constraints will find it easier to increase their finances. Lenders are not worried about the risk of default, so they impose moderate repayment requirements on SMEs. For SMEs with low financial constraints, the increased financial capital will be used to finance profitable business opportunities. This is done by increasing creativity and innovation effectively and efficiently, thereby encouraging higher financial performance. This finding supports the findings of Altaf \& Ahmad (2019), where they also find that companies experiencing financial constraints will find it easier to increase their financial capital because they will more easily access external credit with low loan interest. This also supports the findings of Baños-caballero et al. (2014), where companies that are financially constrained will have a lower optimal working capital point. This means that companies that are financially constrained will find it difficult to increase working capital. When available working capital is limited, this will have a negative impact on financial performance, due to lost sales and discounted payments in the purchase of raw materials.

Model 3 presents the results of testing the moderating effect of financial partners on the relationship between financial capital and the financial performance of SMEs. As has been explained in the literature, financial partners in SMEs are intended for two things. First, to make it easier for them to access external resources. Second, improve capital management effectively and efficiently to encourage better financial performance. Therefore, the proposed hypothesis is that financial partners have a positive moderating effect on the relationship between financial capital and financial performance of SMEs, where the relationship will be stronger when SMEs have financial partners. The results of the data analysis presented in Model 3, show that the positive moderation of financial partners on the relationship between financial capital and financial performance of SMEs is not supported. This can be seen from 
the coefficient of the interaction of financial partners and financial performance which is not significant. This shows that the financial partners that have been established by SMEs have not provided significant benefits for SMEs. On the capital side, existing financial partners have not been able to increase financial capital for SMEs. Meanwhile, in terms of capital management, they have not been able to encourage effective and efficient capital management for SMEs.

Model 4 displays the results of the full moderating effect of financial constraints and financial partners. In this case, financial constraints and financial partners together moderate the relationship between financial capital and the financial performance of SMEs. The results are consistent with Model 2 and Model 3, where only significant financial constraints weaken the relationship, while financial partners are not significant. This means that the financial constraints on SMEs are still very high, while the existing financial partners have not been able to reduce financial constraints. As a result, it is still difficult for SMEs to increase their financial capital, thus hampering performance improvement.

\section{Conclusion and Suggestion}

Based on the results of data analysis, it can be obtained that financial capital is positively and significantly related to the financial performance of SMEs. increase/decrease in financial capital will trigger an increase/decrease in their financial performance. In addition, financial constraints act as a moderator on their relationship. In this case, financial constraints have a negative moderating effect on the relationship, where the relationship is weak because SMEs experience high constraints. Financial partners do not have a significant impact on the relationship. This implies that the existing financial partners have not provided any benefits to SMEs. In terms of capital, financial partners have not been able to increase the financial capital of SMEs. Meanwhile, in terms of capital management, financial partners have also not been able to improve the quality of effective, efficient, and profitable capital management for SMEs.

Based on these findings, regulators should re-evaluate existing policies to address the current problems of SMEs and to assist their development in the future. In general, we find that SME's capital mostly relies on internal capital, and this is very limited. Meanwhile, external capital, whether from bank credit, cooperatives, venture capital, pawnshops, capital assistance from the government, or capital from other sources, hardly helps them. Therefore, most of them are experiencing financial constraints which have a negative impact on their performance and development. In addition, the government's efforts with other stakeholders 
to build financial partnership relationships with SMEs have also not provided significant benefits. Existing financial partners have not been able to increase the capital and performance of SMEs, and have not been able to overcome their financial problems. In particular, we suggest that the government can facilitate them to be able to access free external capital with a simple procedure. This can be done by increasing credit interest subsidies and increasing capital grants to them. In addition, the government can also integrate CSR programs from large companies to improve strategic partnerships for SMEs, especially in the financial sector.

This study measures financial constraints using a dummy variable, which is caused by data limitations. However, the measurement of financial constraints using dummy variables was also carried out by several previous researchers, for example (Altaf \& Ahmad, 2019; Baños-caballero et al., 2014; Belas et al., 2017). However, we acknowledge that the dummy variable is a weak predictor, so it may not fully explain the role of financial constraints on the relationship between financial capital and the financial performance of SMEs. Therefore, future researchers are expected to be able to measure financial constraints using ratios or measurement scales other than a dummy, so that they can explain explicitly. In addition, this study also explores the role of financial partners in the relationship, but the findings show that financial partners do not have a significant role in the relationship. Therefore, future researchers are expected to re-test or develop other test models to further explore the role of financial partners in the relationship.

\section{References}

Abbas, D. (2018). Pengaruh Modal Usaha, Orientasi Pasar, Dan Orientasi Kewirausahaan Terhadap Kinerja Ukm Kota Makassar. Jurnal Minds: Manajemen Ide Dan Inspirasi, 5(1), 95-111. https://doi.org/10.24252/minds.v5i1.4991

Abiodun, D. E. A., \& Amos, D. D. D. (2018). The Performance of Women Entrepreneurs: Human and Financial Capital. Trtiple A Research Journal of Social Science and Humanity (TARJSSH) |, 2(1), 30-037.

Adlešič, R. V., \& Slavec, A. (2012). Social capital and business incubators performance: testing the structural model. Economic and Business Review, 14(3). https://doi.org/10.15458/2335-4216.1227

Altaf, N., \& Ahmad, F. (2019). Working capital financing, firm performance and financial constraints: Empirical evidence from India. International Journal of Managerial Finance, 15(4), 464-477. https://doi.org/10.1108/IJMF-02-2018-0036 
Astley, W. G., \& Ven, A. H. Van De. (1983). Central Perspectives and Debates in Organization Theory. Administrative Science Quarterly, 28(2), 245-273. http://www.jstor.org/stable/2392620

Ayandibu, A. O., \& Houghton, J. (2017). The role of Small and Medium Scale Enterprise in local economic development (LED). Banach Journal of Mathematical Analysis, 11(2), $133-139$.

Bank of Indonesia. (2015). 2015 Economic Report on Indonesia. https://www.bi.go.id/en/publikasi/laporan/Documents/Indonesian Economic Report 2015.pdf

Baños-caballero, S., García-teruel, P. J., \& Martínez-solano, P. (2014). Working capital management, corporate performance, and financial constraints. Journal of Business Research, 67(3), 332-338.

Belas, J., Rahman, A., Rahman, M. T., \& Schonfeld, J. (2017). Financial constraints on innovative smes: Empirical evidence from the visegrad countries. Engineering Economics, 28(5), 552-563. https://doi.org/10.5755/j01.ee.28.5.18204

Beretta, V., Demartini, C., \& Trucco, S. (2019). Does environmental, social and governance performance influence intellectual capital disclosure tone in integrated reporting? Journal of Intellectual Capital, 20(1), 100-124. https://doi.org/10.1108/JIC-02-20180049

Boadi, I., Dana, L. P., Mertens, G., \& Mensah, Lord. (2017). SMEs’ Financing and Banks' Profitability: A “Good Date" for Banks in Ghana? Journal of African Business, 18(2), 257-277. https://doi.org/10.1080/15228916.2017.1285847

Bodlaj, M., Kadic-maglajlic, S., \& Vida, I. (2020). Disentangling the impact of different innovation types, financial constraints and geographic diversification on SMEs ' export growth. Journal of Business Research, 108, 466-475. https://doi.org/10.1016/j.jbusres.2018.10.043

Boohene, R., Gyimah, R. A., \& Osei, M. B. (2019). Social capital and SME performance: the moderating role of emotional intelligence. Journal of Entrepreneurship in Emerging Economies, 12(1), 79-99. https://doi.org/10.1108/JEEE-10-2018-0103

Chittithaworn, C., Islam, A., Keawchana, T., \& Yusuf, D. H. M. (2011). Factors affecting business success of small \& medium enterprises (SMEs) in Thailand. Asian Social Science, 7(5), 180-190. https://doi.org/10.5539/ass.v7n5p180

Dabić, M., Lažnjak, J., Smallbone, D., \& Švarc, J. (2019). Intellectual capital, organisational climate, innovation culture, and SME performance. Journal of Small Business and 
Enterprise Development, 26(4), 522-544. https://doi.org/10.1108/JSBED-04-2018-0117

Dinutistomo, I. A., \& Lubis, A. W. (2021). MSME lending and bank efficiency: Evidence from Indonesia. Banks and Bank Systems, 16(3), 93-103.

Eniola, A. A., \& Entebang, H. (2017). SME Managers and Financial Literacy. Global Business Review, 18(3), 559-576. https://doi.org/10.1177/0972150917692063

Eniola, A., \& Ektebang, H. (2014). SME firms performance in Nigeria: Competitive advantage and its impact. International Journal of Research Studies in Management, 3(2). https://doi.org/10.5861/ijrsm.2014.854

European Commission. (2015). User guide to the SME Definition. The European Union. https://doi.org/10.2873/782201

Fatoki, O. O. (2011). The Impact of Human, Social and Financial Capital on the Performance of Small and Medium-Sized Enterprises (SMEs) in South Africa. Journal of Social Sciences, 29(3), 193-204. https://doi.org/10.1080/09718923.2011.11892970

Gronum, S., Verreynne, M., \& Tim Kastelle. (2012). The Role of Networks in Small and Medium-Sized Enterprise Innovation and Firm Performance. Journal of Small Business Management, 50(2), 257-282.

Kaushik, N., \& Chauhan, S. (2019). The Role of Financial Constraints in the Relationship Between Working Capital Management and Firm Performance. IUP Journal of Applied Finance, 25(1).

Kowsari, A., \& Shorvarzi, M. R. (2017). The Relationship between Working Capital Management, Financial Constraints and Performance of Listed Companies in Tehran Stock Exchange. 10(2), 248-255. https://doi.org/10.5539/jpl.v10n2p248

Laghari, F., \& Chengang, Y. (2019). Investment in working capital and financial constraints: Empirical evidence on corporate performance. International Journal of Managerial Finance, 15(2), 164-190.

Lawrence Neuman, W. (2017). Basics of Social Research: Qualitative and Quantitative Approaches (7th ed.). Pearson Education Limited.

Lukas Menkhoff, Doris Neuberger, \& Ornsiri Rungruxsirivorn. (2012). Collateral and its Substitutes in Emerging Markets' Lending. Journal of Banking and Finance, 36, 817834.

Mcdowell, W. C., \& Harris, M. L. (2009). Relational Orientation and Performance in Micro Businesses. Journal of Business, 21(2), 1-20.

Mofokeng, T. M., \& Chinomona, R. (2019). Supply chain partnership, supply chain collaboration and supply chain integration as the antecedents of supply chain 
Financial capital, constraints, partners, and performance: An empirical analysis of Indonesia SMEs by I Wayan Widnyana, I Made Dauh Wijana, Almuntasir

performance. South African Journal of Business Management, 50(1), 1-10. https://doi.org/10.4102/sajbm.v50i1.193

Nakku, V. B., Agbola, F. W., Miles, M. P., \& Mahmood, A. (2020). The interrelationship between SME government support programs, entrepreneurial orientation, and performance: A developing economy perspective. Journal of Small Business Management, 58(1), 2-31. https://doi.org/10.1080/00472778.2019.1659671

National Agency of Statistics. (2017). Profil Industri Mikro dan Kecil 2017. https://www.bps.go.id/publication/2018/08/15/68ace0c15b5bad8f9adb8cc9/profilindustri-mikro-dan-kecil-2017.html

National Agency of Statistics. (2018). Profil Industri Mikro dan Kecil 2018. https://www.bps.go.id/publication/2019/11/14/355910d12477675c587b918b/profilindustri-mikro-dan-kecil-2018.html

National Agency of Statistics. (2019). Profil Industri Mikro dan Kecil 2019. https://www.bps.go.id/publication/2020/11/16/db2fdf158825afb80a113b6a/profilindustri-mikro-dan-kecil-2019.html

Nooteboom, B. (2000). Institutions and Forms of Co-ordination in Innovation Systems. Organizations Studies, 2(5), 915-939.

Olawale, F., \& Garwe, D. (2010). Obstacles to the growth of new SMEs in South Africa: A principal component analysis approach. 4(May), 729-738.

Omar, C. M. Z. C., \& Azmi, N. M. N. (2020). Factors Affecting the Success of Bumiputera Entrepreneurs in Small and Medium Enterprises ( SMEs ) in Malaysia. International Journal of Management Science and Business Administration, 1(9), 40-45.

Paoloni, P., Modaffari, G., Paoloni, N., \& Ricci, F. (2021). The strategic role of intellectual capital components in agri-food firms. British Food Journal, ahead-of-p(ahead-of-print). https://doi.org/10.1108/BFJ-01-2021-0061

Philip, M. (2011). Factors Affecting Business Success of Small \& Medium Enterprises (SMEs). Amity Global Business Review, 6(1), 118-136.

Prasetya, A., Rahardjo, K., Mawardi, M. K., Rustam Hidayat, R., \& Prakasa, Y. (2021). The mediation role of financial literation in ensuring MSMEs sustainability: An organizational characteristics perspective. JEMA: Jurnal Ilmiah Bidang Akuntansi Dan Manajemen, 18(1), 61. https://doi.org/10.31106/jema.v18i1.10356

Rahman, A., Rahman, M. T., \& Ključnikov, A. (2016). Collateral and SME financing in bangladesh: An analysis across bank size and bank ownership types. Journal of International Studies, 9(2), 112-126. https://doi.org/10.14254/2071-8330.2016/9-2/8 
Rosengard, J. K., \& Prasetyantoko, A. (2011). If the Banks are Doing So Well, Why Can't I Get a Loan? Regulatory Constraints to Financial Inclusion in Indonesia. Asian Economic Policy Review, 6(2), 273-296. https://doi.org/10.1111/j.1748-3131.2011.01205.x

Sadjiarto, A., Santoso, F., \& Nathasia, K. (2020). Motivation Postures and Tax Incentive Towards Tax Compliance of SME in Surabaya During the Pandemic. 5th International Conference on Tourism, Economics, Accounting, Management and Social Science (TEAMS 2020), 433-439.

Sardo, F., Serrasqueiro, Z., \& Alves, H. (2018). On the relationship between intellectual capital and financial performance: A panel data analysis on SME hotels. International $\begin{array}{llll}\text { Journal of } \quad \text { Hospitality } & \text { 67-74. }\end{array}$ https://doi.org/10.1016/j.ijhm.2018.03.001

Setianto, R. H., \& Hayuningdyah, R. (2020). The role of financial constraint on the relationship between working capital management and firms' performance. Advances in Business, Management and Entrepreneurship, April 2019, 281-285. https://doi.org/10.1201/9780429295348-62

Shihadeh, F., Naradda Gamage, S. K., \& Hannoon, A. (M. T. (2019). The causal relationship between SME sustainability and banks' risk. Economic Research-Ekonomska Istraživanja, 32(1), 2743-2760. https://doi.org/10.1080/1331677X.2019.1655465

Sombolayuk, W., Sudirman, I., \& Yusuf, R. M. (2019). Pengaruh modal keuangan terhadap kinerja perusahaan UKM melalui strategi inovasi (Studi Empiris Perusahaan UKM di Kota Makassar). Dinamika Akuntansi, Keuangan Dan Perbankan, 8(2), 134-157.

Sukwadi, R., Wee, H., \& Yang, C. (2013). Supply Chain Performance Based on the LeanAgile Operations and Supplier-Firm Partnership: An Empirical Study on the Garment Industry in Indonesia. Journal of Small Business Management, 51(2), 297-311.

Tambunan, T. T. H. (2011). Development of small and medium enterprises in a developing country. Journal of Enterprising Communities: People and Places in the Global Economy, 5(1), 68-82. https://doi.org/10.1108/17506201111119626

Utari, T., \& Dewi, N. P. M. (2014). Pengaruh modal, tingkat pendidikan dan teknologi terhadap pendapatan Usaha Mikro Kecil dan Menengah (UMKM) di kawasan Imam Bonjol Denpasar Barat. E-JURNAL EKONOMI PEMBANGUNAN UNIVERSITAS UDAYANA, 3(12), 576-585. https://ojs.unud.ac.id/index.php/eep/article/view/9916

World Bank. (2008). Financing Micro, Small, and Medium Enterprises. In Financing Micro, Small, and Medium Enterprises. https://doi.org/10.1596/978-0-8213-7417-7

$\mathrm{Xu}$, J., \& Li, J. (2019). The impact of intellectual capital on SMEs' performance in China. 
Financial capital, constraints, partners, and performance: An empirical analysis of Indonesia SMEs by I Wayan Widnyana, I Made Dauh Wijana, Almuntasir

Journal of Intellectual Capital, 20(4), 488-509. https://doi.org/10.1108/JIC-04-20180074

Zamrudi, Z., \& Wicaksono, T. (2018). Social Commerce Adoption in SME's. JEMA: Jurnal

Ilmiah Bidang Akuntansi Dan Manajemen, 60.

https://doi.org/10.31106/jema.v15i2.1125 